\title{
Congressional Control over Treaty Interpretation
}

\author{
Jamil Jaffer $\dagger$
}

On September 8, 1951, the United States and 47 other Allied Powers signed the Multilateral Treaty of Peace with Japan (Japan-U.S. Peace Treaty). ${ }^{1}$ Article 14 of the treaty provides that the Allied nations will "waive all ... claims of the Allied Powers and their nationals arising out of any actions taken by Japan and its nationals in the course of the prosecution of the war." On March 22, 2001, Congressman Dana Rohrabacher (R-CA) introduced the Justice for United States Prisoners of War Act of 2001 (Justice for POWs Act). ${ }^{3}$ This legislation requires:

In any action in a Federal court brought by one or more [POWs] ... against one or more Japanese nationals ... the court shall not construe section 14(b) of the Treaty of Peace with Japan as constituting a waiver by the United States of claims by nationals of the United States ... so as to preclude the pending action. ${ }^{4}$

During the 107th Congress, the Justice for POWs Act was cosponsored by 229 members of House of Representatives-enough to pass the bill on the floor of the House.

On its face, this legislation raises important questions about Congress's ability to abrogate a treaty by ordering the federal courts to construe the treaty in contravention of its plain meaning. In addition, this legislation implicates the proper balance of power between the legislative, executive, and judicial branches in the creation, interpretation, and revocation of international agreements and compacts.

Using the Justice for POWs Act as a case study, this Comment examines the separation-of-powers issues raised by statutes that attempt to direct the federal courts in the interpretation of treaties and other laws. The goal of this Comment is two-fold: (1) to provide policymakers with a perspective on the constitutional implications of such

\footnotetext{
B.A. 1998, University of California, Los Angeles; J.D. 2003, The University of Chicago. 19523 UST 3169, TIAS No 2490 (1951).

Id at Art 14(b).

3 HR 1198, 107th Cong, 1st Sess, in 147 Cong Rec H 1114 (Mar 22, 2001). Companion legislation was introduced in the Senate on June 29, 2001 by Senator Bob Smith (R-NH). S 1154, 107th Cong, 1st Sess, in 147 Cong Rec S 7193 (June 29, 2001).

4 HR 1198 at \& 3(a) (emphasis added).

5 See Bill Summary and Status for HR 1198, online at http://thomas.loc.gov (visited Feb
} 28,2003 ). 
legislation, and (2) to explain the benefits of taking a formal approach to the consideration of such legislation in the courts. Part I of this Comment briefly describes the historical background of the JapanU.S. Peace Treaty. Part II examines the separation-of-powers doctrine in the statutory and treaty context and notes the latent tension between formalism and functionalism in the Supreme Court's recent separation-of-powers jurisprudence. Part III examines the Justice for POWs Act in the context of the Court's separation-of-powers jurisprudence and explores the formalist-functionalist tension. Part IV proposes that courts adopt a clear statement rule that would require Congress to actually amend or repeal a treaty rather than use the courts to constructively abrogate the treaty, and provides normative justifications for a formalistic approach to the separation of powers in this context.

\section{HISTORY OF THE JAPAN-U.S. CONFLICT AND THE PEACE TREATY}

\section{A. The Experience of U.S. POWs in the War with Japan}

America's direct involvement in World War II began with the surprise Japanese attack on Pearl Harbor on December 7, 1941. While popular memory of World War II generally focuses on the horrors of the war in Europe, the war with Japan was also quite harsh. The extreme brutality of the war with Japan can be seen in the treatment accorded to prisoners of war: While the death rate of U.S. POWs in German camps was approximately 1.2 percent, the death rate of U.S. POWs captured by Japan exceeded 40 percent. ${ }^{6}$ Indeed, some of the most visceral episodes of the American military experience in World War II involved the treatment of captured U.S. soldiers by their Japanese captors. ${ }^{7}$ These events set the stage for the litigation and political

6 See Gary K. Reynolds, U.S. Prisoners of War and Civilian American Citizens Captured and Interned by Japan in World War II: The Issue of Compensation by Japan 11, CRS Report RL30606 (Dec 17,2002), online at http://www.fas.org/man/crs/RL30606.pdf (visited Mar 2, 2003), citing Charles A. Stenger, American Prisoners of War in WWI, WWII, Korea, Vietnam, Persian Gulf, Somalia, Bosnia, Kosovo and Afghanistan: Statistical Data Concerning Numbers Captured, Repatriated, and Still Alive as of January 1, 2002 (unpublished), online at http://www.vba.va.gov/ bln/21/Benefits/POW/docs/POWStatistics2002.doc (visited Mar 1, 2003). For additional information about Japanese war crimes during World War II, see generally Yuki Tanaka, Hidden Horrors. Japanese War Crimes in World War II (Westview 1996).

7 See Former U.S. World War II POW's: A Struggle for Justice, Hearing before the Senate Committee on the Judiciary, 106th Cong, 2d Sess 1 (Jun 28, 2000) (summarizing some of the experiences of U.S. POWs after Allied forces in the Philippines surrendered Bataan to the Japanese). During the event now known as the "Bataan Death March," the Japanese military force in the Philippines marched almost 80,000 starving, sick, and injured Filipino and United States soldiers over 60 miles. Reports of the death toll from the march vary, but it is estimated that between 650 and 2,300 American military personnel died during the march. Reynolds, The Issue of Compensation by Japan at 13 (cited in note 6). Other notable incidents include the transporta- 
disputes that continue to this day over the proper compensation to be afforded American soldiers captured by the Japanese. ${ }^{8}$

\section{B. The Peace Treaty with Japan}

The Japan-U.S. Peace Treaty provides for the waiver of all claims by the Allied powers and their nationals vis-à-vis Japan and its nationals.' In return, the treaty provides each Allied nation with the right to liquidate the assets of Japanese nationals subject to its jurisdiction and, as "an expression of [Japan's] desire to indemnify" Allied POWs for the "undue hardships" they faced while in Japanese custody, the treaty provides for the liquidation and transfer of Japanese assets in neutral countries to the International Committee of the Red Cross with the aim of providing compensation to the POWs and their families. ${ }^{10}$ In the United States, Congress established a War Claims Commission through the War Claims Act of $1948^{11}$ to provide compensation to American POWs. ${ }^{12}$

tion of American POWs in the infamous Japanese "Hell Ships" where thousands more Americans died. Id at 14 . In addition, approximately 25,000 U.S. soldiers were used to perform forced labor in support of the Japanese war effort while interned in Japanese prison camps. Id at 15, citing Linda Goetz Holmes, Unjust Enrichment: How Japan's Companies Built Postwar Fortunes in the Pacific Using American POWs xiii (Stackpole 2001).

8 See Former U.S. World War II POW's at 6-10 (cited in note 7) (statement of David W. Ogden, Acting Assistant Attorney General, Civil Division, U.S. Department of Justice) (discussing pending litigation regarding compensation claims by former U.S. POWs).

9 See Japan-U.S. Peace Treaty at Art 14(b) (providing that the Allies will "waive all ... claims of the Allied Powers and their nationals arising out of any actions taken by Japan and its nationals in the course of the prosecution of the war").

10 See id at Art 16. The minutes of the Japan-U.S. Peace Conference also make it clear that the intention of Articles 14 and 16 was to provide a mechanism for Japan to pay reparations without being completely drained of all of its productive assets. See Conference for the Conclusion and Signature of the Treaty of Peace with Japan: Record of Proceedings 83, US Dept of State Pub 4392 (1951) (statement of John Foster Dulles, Delegate of the United States) (describing the treaty as "a solution ... which gives material satisfaction to the maximum extent compatible with political and economic health in the Pacific area"). At the same time, however, at least one Allied nation objected to the inclusion of the Allied nations "and their nationals" clause in Article 14(b) because of concerns regarding a private right of action for Allied POWs, but the original language was adopted by the Conference. See id at 197 (statement of Dirk U. Stikker, Delegate of the Netherlands) ("It is my Government's view that article 14(b) ... does not involve the expropriation by each Allied Government of the private claims of its nationals so that after the treaty comes into force these claims will be nonexistent.").

11 Pub L No 80-896, 62 Stat 1240, codified at 50 USC $\$ \S 2001-16$ (2000).

12 Chief Justice John Marshall noted that treaties are the law of the land only when they are self-executing because they "operate of [themselves] without the aid of any legislative provision" or, if non-self-executing, when the "legislature ... execute[s] the contract" and makes it "a rule for the Court." See Foster $v$ Neilson, 27 US (2 Pet) 253,314 (1829). It is unclear whether the entire Japan-U.S. Peace Treaty is self-executing because some of the provisions appear to require domestic legislation. However, with regard to the waiver of claims provision, the intent of the treaty-makers appears to be clear with regard to the claims of allied nationals: The treaty is intended to have the domestic effect of barring such claims. See Conference for the Treaty of Peace with Japan at 82-84 (cited in note 10) (statement of John Foster Dulles). In addition, to the ex- 


\section{Efforts to Obtain Additional Compensation}

Following Germany's recent settlement of claims brought by Holocaust survivors, American POW groups sued a number of Japanese companies, ${ }^{13}$ alleging that POWs were forced to engage in labor during the war and claiming a right to compensation under laws designed to assist Holocaust survivors. ${ }^{14}$ These claims were dismissed by a federal judge on September 21, 2000 on the grounds that Article 14(b) of the treaty barred any such claims by American nationals. ${ }^{15}$ The judge held that the plain language of the treaty waived all claims and that both the legislative history and the State Department's understanding of the treaty supported such a reading. ${ }^{16}$ Following this ruling, Congressman Dana Rohrabacher introduced the Justice for POWs Act to "allow American Prisoners of War (POWs) from World War II to file suits against Japanese companies who forced them to perform slave labor during their imprisonment." "This legislation, actively promoted by the POW groups that supported the lawsuit, is directly aimed at ensuring that POWs are able to file claims in U.S. courts and accomplishes this goal by ordering the federal courts to ignore the plain language of the treaty. ${ }^{18}$ While it is clear that Congress may abrogate the treaty if it chooses to do so directly, this legislation raises the serious separation-of-powers issue of whether Congress

tent that this provision may need domestic implementation, it seems reasonable to suggest that the enactment of the War Claims Act of 1948 was designed to carry into effect the bargain reached during the peace conference, and as such, provides domestic effect for these provisions.

13 The Japanese corporations involved include some of the largest companies in Japan: Nippon Steel Corp., Mitsubishi Corp., Mitsui \& Co., Ishikawajima Harima Heavy Industries Co., and Kajima Corp. See, for example, In re World War II Era Japanese Forced Labor Litigation, 114 F Supp 2d 939 (ND Cal 2000) (consolidating several cases against some these companies).

14 See Reynolds, The Issue of Compensation by Japan at 33 (cited in note 6 ).

15 See Japanese Forced Labor Litigation, 114 F Supp $2 \mathrm{~d}$ at 945 ("The treaty by its terms adopts a comprehensive and exclusive settlement plan for war-related economic injuries which [includes a] wholesale waiver of prospective claims."). It has been suggested that individual nations may not bar individual claims brought by their nationals as a matter of international law. See Maki Arakawa, Comment, A New Forum for Comfort Women: Fighting Japan in United States Federal Court, 16 Berkeley Women's L J 174, 190 (2001). However, under U.S. law, it appears clear that in a major foreign policy dispute, the federal government has the ability to settle the claims of its nationals en masse. See Dames \& Moore v Regan, 453 US 654, 688 (1981) (holding that the U.S. government, when acting to resolve a major foreign policy dispute, has the authority to settle claims of its nationals vis-à-vis a foreign power and its nationals).

16 See Japanese Forced Labor Litigation, 114 F Supp 2d at 945-49 (discussing text of the treaty and a statement of interest filed by the Department of State indicating that the executive branch viewed the treaty as barring such claims). See Conference for the Treaty of Peace with Japan at 83 (cited in note 10) (statement of John Foster Dulles, Delegate of the United States) (describing some of the problems that would result "if the treaty validated, or kept contingently alive, monetary reparation claims against Japan").

17 Congressman Dana Rohrabacher, Press Release, Rohrabacher Introduces "Justice for U.S. Prisoners of. War Act of 2001" (Mar 22, 2001), online at http://www.gop.gov/ item-news.asp?docId $=41264$ (visited May 15, 2003).

18 See note 4 and accompanying text. 
may constructively abrogate a treaty through a statutory order directing the federal courts to construe the treaty against its plain meaning.

\section{The Separation of POWERS In Treaties AND StatUTES}

The Supreme Court has often noted "the separation of governmental powers into three coordinate branches is essential to the preservation of liberty." The Court also recognizes that a "hydraulic pressure" exists within each branch to exceed its own structural limits and to attempt to encroach on the powers of the other branches. ${ }^{20}$ In particular, the Framers believed that the legislative branch is prone to encroach upon the judicial and executive power. ${ }^{21}$

The separation-of-powers doctrine, while not explicitly set forth in the Constitution, is nonetheless deeply rooted in the Constitution and is designed to prevent the "commingling" of the various powers of the government. ${ }^{23}$ The Constitution "establishes a judicial department with the province and duty ... to say what the law is in particular cases and controversies." ${ }^{24}$ The assignment of this responsibility to the courts, as opposed to the legislature, is a key part of the separation-ofpowers scheme designed by the Framers. ${ }^{25}$ The separation-of-powers doctrine is designed "both to protect the role of the independent judiciary within the constitutional scheme of tripartite government ... and to safeguard litigants' right to have claims decided before judges who

19 Mistretta $v$ United States, 488 US 361,380 (1989).

20 See INS v Chadha, 462 US 919,951 (1983) (holding unconstitutional a legislative veto provision that allowed one House of Congress to invalidate certain decisions of the executive branch).

21 See Federalist 73 (Hamilton), in Jacob E. Cooke, ed, The Federalist 492, 494 (Wesleyan 1961) (noting the "propensity of the legislative department to intrude upon the rights and to absorb the powers of the other departments"); Federalist 51 (Madison), in Cooke, ed, The Federalist 347, 350 ("In republican government the legislative authority, necessarily, predominates."). See also Mistretta, 488 US at 382 (highlighting the Framers' recognition of "the particular danger of the Legislative Branch's accreting to itself judicial or executive power" and noting that the Court has invalidated efforts by Congress "to exercise the responsibilities of other Branches or to reassign powers vested by the Constitution in either the Judicial Branch or the Executive Branch").

22 See National Mutual Insurance Co v Tidewater Transfer Co, 337 US 582, 590 (1949) (noting the "permeative nature" of the "fundamental" doctrine of separation of powers). See also Mistretta, 488 US at 380.

23 See O'Donoghue $v$ United States, 289 US 516, 530 (1933) (noting that the separation of powers is "basic and vital" and is designed "to preclude a commingling of these essentially different powers of government in the same hands").

24 Plaut v Spendthrift Farm, Inc, 514 US 211, 218 (1995) (holding unconstitutional on separation of powers grounds a provision of the Securities Exchange Act of 1934 that required federal courts to reopen final judgments in private civil actions), quoting Marbury v Madison, 5 US (1 Cranch) 137,177 (1803) (quotation marks omitted).

25 See Plaut, 514 US at 221 (noting the "sharp necessity to separate the legislative from the judicial power"). 
are free from potential domination by other branches of government." ${ }^{26}$

It is in this context of separated powers that one must understand Alexander Hamilton's view that " $[t]$ he interpretation of the laws is the proper and peculiar province of the courts.".77 Understanding how the Supreme Court evaluates the constitutional balance of power regarding the creation, implementation, and interpretation of treaties and statutes can provide a useful window into the application of the separation-of-powers doctrine.

\section{A. Treaties}

1. The role of the various branches in treaty making.

The United States Constitution sets the basic framework for treaties. First, the Constitution provides that the President "shall have Power, by and with the Advice and Consent of the Senate, to make Treaties, provided two thirds of the Senators present concur." ${ }^{28}$ Along with federal statutes and the Constitution itself, the Supremacy Clause of the Constitution provides that treaties made according to the constitutional process are the "supreme Law of the Land.", Finally, because the Constitution places treaties on the same footing as federal statutes such that neither is superior to the other, ${ }^{30}$ subsequent acts of Congress may enforce, modify, or repeal a treaty and its provisions. ${ }^{31}$

\section{Abrogation or modification of treaties.}

The Court has long held that the choice to renege on a promise made in a treaty is a matter best left to the political branches of the government. ${ }^{32}$ Such modifications or repeals are accomplished through

26 Commodity Futures Trading Commission v Schor, 478 US 833, 848 (1986) (quotation marks and citations omitted) (holding that the Commodity Exchange Act empowers the Commodity Futures Trading Commission to entertain state law counterclaims in reparations proceedings, and holding that this power does not violate Article III of the Constitution).

27 Federalist 78 (Hamilton), in Cooke, ed, The Federalist 521, 525 (cited in note 21).

28 US Const Art II, $\$ 2, \mathrm{cl} 2$.

29 US Const Art VI, cl 2.

30 See Whitney v Robertson, 124 US 190, 194 (1888) ("Both [congressional legislation and treaties] are declared by [the Constitution] to be the supreme law of the land, and no superior efficacy is given to either over the other."). See also The Chinese Exclusion Case, 130 US 581,600 (1889) (same).

31 See Head Money Cases, 112 US 580, 599 (1884) (discussing the effect on treaties of subsequent federal statutes). It is important to note that such action by Congress would only have a direct effect domestically. In the international realm, the repeal of a treaty provision would simply force the U.S. to go into default on its treaty obligations. Louis Henkin, Foreign Affairs and the United States Constitution 209-10 (Oxford 2d ed 1996) ("Acts of Congress inconsistent with earlier treaty obligations... [do] not affect the validity of the treaty and its continuing international obligations for the United States, but it compels the United States to be in default.").

32 See Whitney, 124 US at 195 (noting that the choice to act in direct contravention of a 
the passage of federal legislation, which, under the Supremacy Clause, has the same force as a treaty. ${ }^{33}$ As with any ordinary legislation, if an act of Congress and a treaty relate to the same subject, the courts will construe them to give effect to both. ${ }^{34}$ However, if doing so would violate the language of either, the most recent provision will control. ${ }^{35}$ This rule of interpretation is subject to one caveat: Congress must clearly express its intent to abrogate a treaty provision in order for it to be effective. ${ }^{36}$ The Court has never confronted the question of whether an interpretive directive to the federal courts to construe a treaty against its plain meaning satisfies this requirement.

\section{Treaty interpretation.}

The interpretation of a treaty is divided among the three coordinate branches of government. Because the President is the "sole organ" of the federal government in the field of international relations, he possesses a "plenary and exclusive" power in the realm of foreign affairs. ${ }^{37}$ Of course, this power is cabined by constitutional provisions that require him to share certain foreign policy powers with the other branches. ${ }^{38}$ As a result of his central role in foreign policy, the President generally has the authority to interpret treaties in the international arena. ${ }^{39}$ For this reason, the Court gives a great deal of weight to

treaty "belong[s] to diplomacy and legislation, and not to the administration of the laws").

33 See US Const Art VI, cl 2 ("[T]he Laws of the United States ... and all Treaties made ... under the Authority of the United States, shall be the supreme Law of the Land."); Whitney, 124 US at 194 ("By the Constitution a treaty is placed on the same footing, and made of like obligation, with an act of [congressional] legislation.").

34 See Whitney, 124 US at 194.

35 See The Chinese Exclusion Case, 130 US at 600 ("[T] will must control."); Whitney, 124 US at 194 ("[1]f there be any conflict between the stipulations of the treaty and the requirements of the law, the latter must control.").

36 See, for example, Cook $v$ United States, 288 US 102, 120 (1933) (holding that the reenactment of a piece of federal legislation would not abrogate a treaty provision where the legislative record indicated no intent to directly modify or repeal that provision); Foster \& Elam v Neilson, 27 US (2 Pet) 253, 307 (1829) (holding that in order to abrogate a treaty Congress's intent to do so must be "clearly expressed" and the "course of the nation has ... [to be] plain"); Norman J. Singer, 1A Sutherland Statutory Construction $\$ 32.08$ at 569 (Clark Boardman Callaghan 5th ed 1993) ("As a matter of interpretation, the intent to abrogate a treaty provision by a later act of Congress must be clearly expressed in order for it to have that effect.").

37 United States v Curtiss-Wright Export Corp, 299 US 304, 320 (1936) (upholding the constitutionality of a joint resolution by Congress and a presidential proclamation that made the sale of arms to countries engaged in armed conflict in the Chaco a criminal offense).

38 See, for example, US Const Art II, § 2, $\mathrm{cl} 2$ (dividing the Treaty Power and the appointment of Ambassadors between the President and the Senate). See also, US Const Art I, $\S 8, \mathrm{cl} 11$ (providing Congress with the power to "declare war"); US Const Art II, \& 2, cl 1 (providing that the President shall be the commander in chief).

39 Restatement (Third) of the Foreign Relations Law of the United States $\$ 326$, cmt a (1987) ("The President has authority to interpret international agreements for the purpose of United States foreign relations since he is the country's 'sole organ' in its international relations and is responsible for carrying out agreements with other nations."). 
the interpretation of an international agreement by the executive branch.

Because of its constitutionally mandated role in the treatymaking process, the Senate plays a part in the initial interpretation of a treaty and may condition its consent on the adoption of certain provisions or understandings. ${ }^{41}$ However, the Supreme Court has held that the Senate's ability to put forward its understanding of a treaty does not extend beyond the ratification stage. ${ }^{42}$ Thus, while the President and the Senate have the power to interpret treaties in the first instance because treaties are a form of federal law, ${ }^{43}$ the courts have carefully guarded their role as the final expositors of the meaning of international agreements as they apply to cases and controversies before the courts."

Courts, in interpreting a treaty, must begin with the language of the treaty itself; the "clear import of treaty language" controls a court's interpretation. ${ }^{45}$ In addition, where adherence to the plain meaning of a treaty's text would further the treaty's purposes, such a

40 See Sumitomo Shoji America, Inc $v$ Avagliano, 457 US 176, 184-85 (1982) (holding that while the executive branch's interpretation of a treaty is not conclusive, it is entitled to great weight).

41 See Curtis A. Bradley and Jack L. Goldsmith, Treaties, Human Rights, and Conditional Consent, 149 U Pa L Rev 399, 404-10 (2000) (discussing the respective roles of the Senate and President in the treaty-making process); Restatement (Third) of Foreign Relations Law $\$ 326$, cmt a (cited in note 39) ("Interpretation by the Senate of a treaty after it has been concluded may have no special authority, but understandings expressed by the Senate in giving its advice and consent must be respected.").

42 See Fourteen Diamond Rings v United States, 183 US 176, 180 (1901) ("The meaning of the treaty cannot be controlled by subsequent explanations of some of those who may have voted to ratify it."). See also Restatement (Third) of Foreign Relations Law $\S 326$, cmt a (cited in note 40). The notion underlying the Supreme Court's limited view of the Senate's role in interpreting treaties seems directly tied to the constitutional role assigned to the Senate. That is, the Senate's role is limited by the Constitution to providing "advice and consent" (including ratification by a two-thirds margin) to the President in his "making" of a treaty. See US Const Art II, $\S 2$, cl 2 . As a result, the ratification process that gives a treaty legal effect affords the Senate a role at the outset but does not provide the Senate with a role in interpretation post-ratification. Normatively, this seems to be a reasonable approach, particularly when contrasted with the deference afforded to the executive. Additional deference to the executive is reasonable in light of the broader foreign affairs powers the Constitution assigns to the President. In addition, as noted earlier, the Senate does have a role to play in amendment or abrogation domestically, at least, through application of the last-in-time rule.

43 See US Const Art VI, cl 2 ("[A]ll Treaties made, or which shall be made, under the Authority of the United States, shall be the supreme Law of the Land."). See also note 33 and accompanying text.

44 See Jones v Meehan, 175 US 1, 32 (1899) ("The construction of treaties is the peculiar province of the judiciary."). See also Japan Whaling Association v American Cetacean Society, 478 US 221, 230 (1986) (noting that the political question doctrine would not bar judicial construction of treaties and relevant statutes).

45 Sumitomo, 457 US at 180 (construing the Friendship, Commerce, and Navigation Treaty between the United States and Japan). 
plain reading is preferred. ${ }^{46}$ In evaluating the plain meaning of a treaty, the court may examine whether such a reading is consistent with a variety of other sources, ${ }^{47}$ including the discussions between the parties during negotiations, other provisions of the treaty, and the current interpretation of the treaty by both parties. ${ }^{48}$ When examining these sources, the Supreme Court has emphasized that courts should be mindful that their primary role in interpreting treaties is to give effect to the intent of the parties involved, ${ }^{49}$ essentially treating a treaty as a contract between sovereign states.

\section{B. Statutes}

For the purposes of amendment and repeal, treaties are functionally equivalent to statutes. ${ }^{\text {s1 }}$ Because the Justice for POWs Act attempts to use the federal courts to constructively abrogate the JapanU.S. Peace Treaty, it is important to examine the Court's jurisprudence regarding interpretive statutes.

1. Interpretive statutes and the courts.

The interpretation of a prior statute by a later Congress is generally not binding on the courts. ${ }^{52}$ However, some treatise writers have suggested that interpretive statutes are "increasingly" being treated as binding by the lower federal courts. ${ }^{53}$ For example, in some cases, courts have permitted Congress to define terms used in prior legislation through subsequent action, ${ }^{\text {s4 }}$ acquiesce in an agency interpretation

46 See id at $185-88$ (discussing the agreement between the plain meaning and purpose of the treaty).

47 See id at $182-85$.

48 See id.

49 See id at 185.

50 See Fourteen Diamond Rings, 183 US at 182-83 (stating that a treaty "differs from an ordinary contract only in being an agreement between independent states instead of private parties"). It is important to note that as a contract, the breach of a treaty has a variety of implications under international law. See, for example, the Vienna Convention on the Law of Treaties, 8 ILM 679, Arts 54-64 (1969) (U.S. not a party) (discussing the termination and suspension of the operation of treaties).

51 See Whitney, 124 US at 194.

52 See United States $v$ Wise, 370 US 405, 414 (1962) (holding that the views of the 1914 Congress were "not of weight" for the purpose of interpreting an 1890 act); United States $v$ Stafoff, 260 US 477, 480 (1923) ("[A] statute purporting to declare the intent of an earlier one ... [is] not entitled to control judicial action.").

53 See, for example, Singer, 1A Sutherland Statutory Construction $\$ 27.04$ at $472-74$ (cited in note 36) (discussing interpretive statutes and citing district court cases that treat such statutes as binding).

54 See Ace Waterways v Fleming, 98 F Supp 666, 667 (SD NY 1951) (holding that Congress may "legislate by definition" even when it chooses to define "steam vessels" so as to include all vessels powered by "steam or by any other form of mechanical or electrical power"). 
of an earlier statute, ${ }^{5 s}$ or indicate its current understanding of prior legislation. ${ }^{\text {s6 }}$ However, in the third arena, where Congress acts to express its current view of an existing statute, Judge Learned Hand wrote: "Congress may no doubt indicate its understanding as to the scope of its former words ... but its interpretation as such is immaterial. [Congress] is as likely to be wrong as any one else, and in the end the courts must decide:",

In a subsequent case, Judge Hand went even further, and noted that "legislative interpretation is immaterial ... in that the courts alone may in the end declare what a statute means." Congress expresses its view of an extant statute, the judiciary appears committed to retaining the final authority to ascertain the proper application of the statute in a case before the courts. Assigning such a role to the courts makes sense in the context of a divided government, where the legislature is responsible for enacting laws, the executive is responsible for implementing the laws, and the judiciary is responsible for interpreting the laws.

2. Adjudicating interbranch conflicts and the tension between functionalism and formalism.

Although the separation-of-powers doctrine is essential to our constitutional framework, it is not designed to isolate the three coordinate branches from one another. ${ }^{60}$ Rather, when a conflict between two or more branches arises, the Court has historically noted that the judiciary must take "a pragmatic, flexible approach" in the adjudica-

55 See Sterling Oil \& Gas Co v Lucas, 51 F2d 413,416 (WD Ky 1931) (holding that where a longstanding agency ruling has the sanction of the legislature, the "departmental and legislative construction is binding upon the courts").

56 See Fire Companies Building Corp v Commissioner of Internal Revenue, 54 F2d 488, 489 (2d Cir 1931) (noting that when Congress indicates its understanding of prior statutes, "and when this can be treated as a command, it will control, subject to constitutional limits").

57 Id.

58 American Exchange Securities Corp v Helvering, 74 F2d 213, 214 (2d Cir 1934).

59 This is not to suggest that Congress loses any of its legislative power when the courts guard their interpretive authority - just the opposite. Interpretive statutes essentially seek to involve the courts in the legislative process, directing the judiciary in the interpretation of prior statutes without legislative amendment of the underlying statutory text. Where courts guard their own role in interpretation, they preserve Congress's ability to legislate directly on a given subject. Such an understanding of the role of the courts can be applied in both the statutory and treaty contexts.

60 See United States v Nixon, 418 US 683, 707 (1974) ("[T]he separate powers were not intended to operate with absolute independence."); United States $v$ Brainer, 691 F2d 691, 697 (4th Cir 1982) ("The principle of the separation of powers does not set the three branches of government apart in absolute isolation."). See also Youngstown Sheet \& Tube Co v Sawyer, 343 US 579,635 (1952) (Jackson concurring) ("While the Constitution diffuses power the better to secure liberty, it also contemplates that practice will integrate the dispersed powers into a workable government. It enjoins upon its branches separateness but interdependence, autonomy but reciprocity."). 
tion of these conflicts. ${ }^{61}$ At the same time, more recent Supreme Court cases suggest that a more formalistic approach may be warranted where structural constitutional norms are at issue. ${ }^{62}$ This tension between a formal, bright-line separation between the legislative and judicial power on one hand, and a more flexible approach on the other, animates recent Supreme Court cases in this arena. ${ }^{63}$

In order to understand how this debate between functionalism and formalism has developed in the statutory context, it is necessary to examine the cases in which the Court initially explored the line between judicial and legislative power. In Pennsylvania $v$ Wheeling \& Belmont Bridge Co (Wheeling Bridge I), ${ }^{64}$ the Supreme Court designated a bridge between Virginia and Pennsylvania as a nuisance to navigation and entered an injunction to have the bridge either raised or removed. ${ }^{\text {ts }}$ Following the Supreme Court's ruling, Congress passed a law that declared the bridge a post-road and prohibited navigation from interfering with the bridge. ${ }^{60}$ In a subsequent case, Pennsylvania $v$ Wheeling and Belmont Bridge Co (Wheeling Bridge II), the Supreme Court examined Congress's action and held that Congress was permitted to alter the prospective effects of the earlier injunction because Congress had altered the underlying substantive law.

Sixteen years later, in United States $v$ Klein, ${ }^{69}$ the Supreme Court struck down a federal statute that required the Court to dismiss a set of cases decided in the lower courts without any actual review by the

61 See Nixon v Administrator of General Services, 433 US 425, 442-43 (1977) (indicating that such a "pragmatic, flexible approach" is necessary because the Court has "squarely rejected the argument that the Constitution contemplates a complete division of authority between the three branches" and noting that the Court has essentially adopted Justice Jackson's view expressed in his Youngstown concurrence). See also Brainer, 691 F2d at 697 ("The principle of the separation of powers does not set the three branches of government apart in absolute isolation.").

62 See, for example, Plaut, 514 US at 218-25 (noting that the important structural nature of the separation of the powers doctrine, when combined with the longstanding threat of legislative encroachment on the powers of the judiciary, provides an important reason for the judiciary to ensure that such encroachment is carefully monitored).

63 Contrast id (adopting the formalist approach to the separation of powers doctrine), with Robertson $v$ Seattle Audubon Society, 503 US 429 (1992) (adopting a flexible approach to the separation of powers doctrine).

6454 US (13 How) 518 (1852).

65 See id at 577-79.

66 See Pennsylvania $v$ Wheeling \& Belmont Bridge Co, 59 US (18 How) 421, 431-32 (1855) (Wheeling Bridge II).

6759 US (18 How) 421 (1855).

68 See id at 431-32. The decree entered in Wheeling Bridge I provided for prospective injunctive relief, not damages at law, the ongoing validity of which depended on whether or not the bridge interfered with the right of navigation. When Congress altered the underlying law such that the bridge was no longer an unlawful obstruction, the injunction against the maintenance of the bridge was not enforceable.

6980 US (13 Wall) 128 (1871). 
Supreme Court. ${ }^{70}$ The Court held that such a statute constituted an invalid attempt by Congress to "prescribe rules of decision" to be followed by the judiciary, ${ }^{11}$ and that such an attempt to cabin the authority of the federal courts "passed the limit which separates the legislative from the judicial power." ${ }^{\prime 2}$ The fundamental distinction between Wheeling Bridge II and Klein was that in Wheeling Bridge II Congress had not prescribed a different decision under the same law, but rather had altered the law and left the court to "apply its ordinary rules to the new circumstances created by the act." "73

The distinction that the Court drew between altering the substantive law on the one hand, and prescribing a rule of decision on the other, has proven to be extremely difficult to apply in practice. Indeed, the Supreme Court recently noted that the exact boundaries of its holding in Klein are unclear. ${ }^{74}$ Although this jurisprudence has been the subject of dispute in recent years, courts are still unable to articulate a clear distinction between the Wheeling Bridge II line of cases and the Klein line of cases. ${ }^{75}$ Doing so, however, is critical. The difference between altering the substantive law and prescribing a rule of decision goes to the core of the separation of powers. In altering substantive law, Congress is clearly acting under its legislative powers granted in Article I. ${ }^{76}$ However, by prescribing "rules of decision" for the judiciary, Congress prevents the courts from exercising their Article III role as interpreters of the law." In this way, the distinction between Wheeling Bridge II and Klein can be seen as a border in the constitutional separation of powers that exists between Congress and the courts. By applying this developing line of cases, and the distinc-

70 In Klein, the Supreme Court dealt with the case of a Confederate sympathizer who had received a presidential pardon for his involvement in the Civil War and whose estate attempted to recover the proceeds of the sale of cotton seized during the war. Klein attempted to recover under a statute that allowed noncombatant Confederate landowners to recover the value of their land upon proof of loyalty to the federal government. The Court of Claims ruled that under prior Supreme Court precedent, the receipt of a pardon was sufficient proof of loyalty and, as such, Klein was entitled to recovery. While the government's appeal was pending, Congress passed a statute declaring that presidential pardons were evidence of disloyalty and purported to direct the Supreme Court to dismiss any case where the claimant had prevailed by showing proof of loyalty based on a presidential pardon. See id at 136-47.

71 Id at $146-48$.

72 Id at 147.

73 Id.

74 See Plaut, 514 US at 218.

75 See, for example, Miller v French, 530 US 327 (2000) (holding that a provision of a statute did not unconstitutionally suspend or reopen an Article III court's judgment, but simply reflected the change implemented in another provision of the same statute that established new standards for prospective relief); Robertson, 503 US at 437 (finding that the statute in question did not change legal results, but changed the underlying law).

76 See US Const Art I, $\$ 1$.

77 See US Const Art III, §§ 1-2; Federalist 78 (Hamilton) at 525 (cited in note 27) ("The interpretation of the laws is the proper and peculiar province of the courts."). 
tion the cases attempt to draw, to the Justice for POWs Act, this Comment explores the tension between functionalism and formalism and attempts to draw a few lessons about the proper scope of the separation of powers. In the end, this Comment argues that the separation-of-powers doctrine is clearly implicated by the Justice for POWs Act and that a formalistic approach to the doctrine is necessary to ensure that the carefully crafted balance created in the Constitution is preserved.

\section{FUNCTIONALISM VERSUS FORMALISM: ANALYZING THE JUSTICE FOR POWS ACT}

The question that the Wheeling Bridge II/Klein line of cases raises with respect to the Justice for POWs Act is whether the Act, through its order to the federal courts to construe the Japan-U.S. Peace Treaty against its plain meaning, is a permissible attempt to change existing law or an improper attempt to prescribe a rule of decision for the federal courts. Sorting through this question by examining the Supreme Court's case law in this area and applying it to the Justice for POWs Act reveals a latent tension between the functionalist and formalistic approaches to the separation of powers. It is this tension that the latter part of the Comment attempts to resolve by arguing that the formal approach is normatively superior and comports best with the Supreme Court's most recent decisions regarding the proper separation of powers.

\section{A. Stockdale and Robertson-Functionalism Applied}

Over one hundred years ago, the Supreme Court began taking a functional approach to the separation of powers between the judiciary and the legislative branch. In 1873, the Court dealt with a statute in which Congress used language similar to that contained in the Justice for POWs Act and upheld Congress's ability to legislate through the use of a "shall construe" directive to the federal courts. ${ }^{78}$ In Stockdale $v$ Insurance Cos, the Supreme Court confronted a tax statute designed to amend and eliminate various tax provisions. ${ }^{80}$ Part of the statute declared that certain existing tax laws, as modified, "shall be construed" to impose the taxes on a specific date and that after that date the taxes would no longer be levied or assessed. ${ }^{81}$ Citing Wheeling Bridge II for the proposition that Congress may alter an existing law with prospec-

78 See Stockdale v Insurance Cos, 87 US (20 Wall) 323, 332-33 (1873) (interpreting the use of a "shall construe" directive as an attempt to substantively amend an earlier statute).

7987 (20 Wall) US 323 (1873).

80 Id at $330-31$.

81 Id at 331. 
tive effect, the Court in Stockdale held that the use of a directive to the courts would not be viewed as an "invasion" of the judicial power when Congress properly has the power and ability to legislate. ${ }^{82}$ As such, the "unfortunate and unnecessary use of the word "construe"" did not invalidate the tax measure. ${ }^{83}$ On its face, this case seems to suggest that, at least in areas where Congress may properly legislate, the form of the statute is irrelevant and the Court will view an interpretive directive to the judiciary as an attempt to substantively amend the underlying law. ${ }^{84}$

More recent cases seem to support this reading of Stockdale and the Wheeling Bride II/Klein line of cases. In Seattle Audubon Society $v$ Robertson $^{85}$ (Seattle Audubon), the Ninth Circuit dealt with litigation brought by environmental groups to force the government to comply with a variety of federal environmental laws. ${ }^{86}$ In response to the ongoing litigation, Congress enacted a legislative compromise that provided: "Congress hereby determines and directs that management of [certain public lands] is adequate consideration for the purpose of meeting the statutory requirements that are the basis for the consolidated cases captioned Seattle Audubon Society et al., v. F. Dale Robertson, Civil No. 89-160 ...."

At first glance, the legislation appears to set forth an impermissible rule of decision in a specific set of cases in clear violation of the Klein principle. Indeed, the Seattle Audubon plaintiffs aggressively argued this position, pointing to the mandatory language used by Congress and the actual identification of the affected cases in the text of the statute. The Ninth Circuit agreed and held that the legislation improperly intruded upon the judiciary's power to adjudicate cases properly before the courts. ${ }^{88}$ The court held that the legislation "does not, by its plain language, repeal or amend" the underlying law, but attempts to "direct the court to reach a specific result and make certain factual findings under existing law" - a result prohibited by Klein. ${ }^{89}$ On appeal, in Robertson $v$ Seattle Audubon Society ${ }^{90}$ (Robertson), the Supreme Court reversed the Ninth Circuit and held that rather than pre-

\footnotetext{
See id at 332 .

Id at $331,333$.

See id at 332-33.

85914 F2d 1311 (9th Cir 1990), revd, Robertson v Seattle Audubon Society, 503 US 429

86 See Seattle Audubon, 914 F2d at 1312-13.

87 Department of Interior and Related Agencies Appropriations Act of 1990, Pub L No 101-121, § 318(b)(6)(A), 103 Stat 701, 747 (1989).

88 See Seattle Audubon, 914 F2d at 1317 ("Congress did not amend or repeal laws, as it unquestionably could do, but rather prescribed a rule for the decision of a cause in a particular way, without changing the underlying laws, as it unquestionably cannot do.").

89 Id at 1316.

90503 US 429 (1992).
} (1992). 
scribing a rule of decision, Congress had actually modified the underlying law through the subsequent legislative compromise. held that if Congress has the ability to change the underlying law (and appears to have done so), the use of imperative language will not render the statute invalid as a usurpation of judicial authority under Klein."

Taken together, Stockdale and Robertson seem to indicate that the Court is taking a more functional approach to Klein-type cases. Under this "flexible" approach, because Congress clearly has the power to amend or abrogate a treaty through subsequent legislation, even the use of statutory language that appears to direct the judiciary's construction of a treaty is unlikely to affect the statute's validity. In particular, Robertson seems to suggest that this will be true even when such legislation clearly takes the form of a direct order to the federal courts.

As a result, when examined solely in the context of Robertson and Stockdale, the Justice for POWs Act appears likely to withstand a separation-of-powers challenge as a valid exercise of Congress's acknowledged ability to alter a treaty through subsequent legislation.

\section{B. The Court's Renewed Formalism}

However, this is not the end of the story. It is important to note that the Court's decision in Robertson came prior to the Rehnquist Court's recent efforts to police what some have termed "underenforced constitutional norms." "In 1992, the year that Robertson was decided, law professors William Eskridge and Phillip Frickey identified two such underenforced norms: federalism limitations on congressional action and the separation-of-powers doctrine. Since 1992, taking up Eskridge and Frickey's challenge, the Supreme Court has begun to enforce federalism limitations in cases like United States $v$ Lopez, ${ }^{96}$ United States $v$ Morrison, ${ }^{97}$ and Printz v United States. ${ }^{98}$ Simi-

91 See id at $438-41$.

92 See id at 439.

93 See Head Money Cases, 112 US 580, 599 (1884) ("[S]o far as a treaty made by the United States with any foreign nation can become the subject of judicial cognizance ..., it is subject to such acts as Congress may pass for its enforcement, modification, or repeal.").

94 See Lawrence Gene Sager, Fair Measure: The Legal Status of Underenforced Constitutional Norms, 91 Harv L Rev 1212 (1978).

95 See William N. Eskridge, Jr. and Philip P. Frickey, Quasi-Constitutional Law: Clear Statement Rules as Constitutional Lawmaking, 45 Vand L Rev 593, 630-31 (1992).

96514 US 549 (1995) (invalidating the Gun-Free School Zones Act of 1990 because Congress lacked the power to enact the statute under the Commerce Clause).

97529 US 598 (2000) (invalidating the civil remedy provided in the Violence Against Women Act of 1994 because Congress lacked the authority to enact the statute under either the Commerce Clause or the Fourteenth Amendment).

98521 US 898 (1997) (invalidating interim provisions of the Brady Act because they vio- 
larly, in the separation-of-powers arena, the Supreme Court's decisions in Plaut $v$ Spendthrift Farm, Inc ${ }^{99}$ in 1995 and City of Boerne $v$ Flores $^{100}$ in 1997 appear to indicate a new willingness on the part of the Supreme Court to carefully scrutinize legislative efforts to intrude upon the role historically assigned to the judiciary. ${ }^{101}$ More importantly, these cases also appear to indicate a new willingness by some members of the Court to engage in a more formalistic approach to enforcing such underenforced norms. ${ }^{102}$ Supporters of this trend believe that a formalistic approach to enforcing these structural safeguards, such as the separation of powers, is crucial. As the Court pointed out in Printz:

Much of the Constitution is concerned with setting forth the form of our government, and the courts have traditionally invalidated measures deviating from that form. The result may appear "formalistic" in a given case ... [b]ut the Constitution ... divides power among sovereigns and among branches of government precisely so that we may resist the temptation to concentrate power in one location. ${ }^{103}$

This formalistic approach to the separation of powers embodied in the Court's more recent cases appears to conflict with the Court's historically more functional approach.

\section{Latent Tensions-Functionalism versus Formalism}

If the Court were to face a constitutional challenge to the Justice for POWs Act under the Klein separation-of-powers doctrine, it is far from clear that Robertson would control the result. Indeed, the Court's divergent jurisprudence establishes a latent tension between the Plaut approach, in which formalism is used to enforce the separation-of-powers doctrine to protect the judiciary from legislative encroachment, and the Robertson approach, in which a more "flexible

lated state sovereignty by compelling states and state officials to administer a federal regulatory scheme).

99514 US 211 (1995).

100521 US 507 (1997) (holding Religious Freedom Restoration Act unconstitutional on separation of powers grounds).

101 See, for example, id at 536 (discussing the role of the judiciary vis-à-vis the legislature in interpreting the Constitution); Plaut, 514 US at 227-33 (noting that serious separation of powers issues are raised when Congress attempts to undertake a role properly assigned to the judiciary).

102 See Benjamin v Jacobson, 172 F3d 144, 179-80 (2d Cir 1999) (en banc) (Calabresi concurring) (discussing the "formal structure of the separation of powers doctrine" and the Supreme Court's move towards formalism in federalism and separation of powers cases).

103521 US at 933, quoting New York v United States, 505 US 144, 187 (1992) (quotation marks omitted). It is true that New York was decided a scant three months after Robertson. However, when viewed in the context of the Court's federalism and separation of powers rulings since Robertson, it seems clear that the Court is pursuing these constitutional values with a renewed formalist vigor. 
and pragmatic" view is taken in addressing a potential conflict between the branches and is eventually resolved in favor of the legislature. $^{104}$ The Justice for POWs Act provides a useful case study for examining how this tension may be addressed.

It might be assumed that the Supreme Court is likely simply to apply the more recent Plaut approach in order to protect the separation-of-powers doctrine. However, there are two major barriers to the Court applying its renewed fervor for formalism to the Justice for POWs Act. First, courts are generally loath to interpret statutes in ways that raise serious constitutional questions. ${ }^{105}$ In the case of the Justice for POWs Act, if the Court applies the formalism of Plaut, it is likely to determine that the Act is unconstitutional. Therefore, one might expect application of the canon of constitutional avoidance to lead the court to apply the more flexible approach adopted in Robertson. Even more importantly, if the Court were to apply a more formal approach to such legislation, it faces the serious problem of having to either overrule Robertson explicitly, or interpret its holding so narrowly as to eviscerate Robertson's precedential value. Given the current Court's concern with the doctrine of stare decisis, ${ }^{106}$ it seems unlikely to engage in such an exercise without good reason to do so.

At the same time, however, in the Supreme Court's most recent application of the Klein doctrine, Miller $v$ French, ${ }^{107}$ the Court held that where Congress expresses a clear intent, the Court must give effect to that intent even if that means confronting a constitutional question. ${ }^{108}$ As such, if a strong argument can be made that Congress's clear intent in passing the Justice for POWs Act was to constructively abrogate the Japan-U.S. Peace Treaty, and if there are strong reasons for taking a more formal approach to the separation of powers, the Court will

104 For an excellent introduction to the formalist-functionalist debate, see Adrian Vermeule, The Judicial Power in the State (and Federal) Courts, $2000 \mathrm{~S} \mathrm{Ct} \mathrm{Rev} \mathrm{357,} \mathrm{362-70.}$

105 See Communications Workers of America v Beck, 487 US 735, 762 (1988) (holding that the courts should avoid a constitutionally doubtful construction of a statute where "fairly possible").

106 See, for example, Planned Parenthood of Southeastern Pennsylvania v Casey, 505 US 833, 854-61 (1992) (applying the doctrine of stare decisis to strike down, in part, a Pennsylvania abortion statute).

107530 US 327 (2000).

108 See id at 341 . In Miller, the Court faced a Wheeling Bridge II/Klein challenge to the Prison Litigation Reform Act and squarely confronted the constitutional question of whether Congress could prohibit federal courts from exercising their equitable authority to suspend the operation of an automatic stay. See id at 331. The Court rejected the constitutional challenge and held that because the PLRA dealt with prospective equitable relief, it was a valid effort by Congress to change the underlying law based on Wheeling Bridge II, and therefore did not reopen a final judgment of the federal courts under Plaut. See id at 346-48. In addition, the Court held that the Klein challenge on separation of powers grounds could not be upheld since the potentially problematic stay provision was directly tied to valid, substantive change in the underlying law. See id at 344-49. 
likely confront the constitutional separation-of-powers question head on.

\section{Proposed Solution-The Clear Statement Rule}

Although it is unclear whether the Court would apply a formal or functional approach to the Justice for POWs Act, the best approach to this statute (and others that attempt to engage in similar encroachments on the judicial role) is the formal approach taken in the Klein line of cases. Formalism preserves the separation of powers and prevents Congress from directing the courts to interpret a statute in a given manner, even where (and perhaps particularly where) Congress has the power to amend the statute directly. By requiring that Congress directly abrogate the treaty or statute in question, the Court can ensure that Congress does not hide behind the federal courts to avoid paying the steep, up-front political costs of its actions. In addition, such a mechanism would recognize the primary role that the political branches play in foreign affairs and would allow the courts to avoid entanglement in this politically sensitive arena.

One way the Court may accomplish this is by applying a clear statement rule to legislative efforts to amend or abrogate a treaty. Such a rule would require Congress to be "unambiguous" in a statute aimed at amending a substantive provision of a treaty. The application of this rule would require Congress to actually amend the underlying substantive law, rather than using the courts as a tool to constructively. abrogate the treaty. That is, in order for a statute to be "clear enough" to comply with the rule, Congress must directly do what the Justice for POWs Act would instead accomplish through a directive to the courts.

\section{A. Benefits of the Clear Statement Approach}

The Court has increasingly employed the clear statement rule in protecting other structural constitutional provisions in order to ensure that Congress carefully considers its attempts to override such constitutionally grounded values. ${ }^{10}$ In addition, the Court often uses clear statement rules to support various canons of statutory construction. For example, the Supreme Court has used clear statement rules in the past to reinforce or apply the canon of constitutional avoidance and

109 See Edward J. DeBartolo Corp v Florida Gulf Coast Building \& Construction Trades Council, 485 US 568, 575 (1988) (noting that the canon of constitutional avoidance may only be applied where the saving construction is not "plainly contrary to the intent of Congress"); United States $v$ Locke, 471 US 84, 96 (1985) ("We cannot press statutory construction to the point of disingenuous evasion even to avoid a constitutional question.") (quotation marks omitted).

110 For a general discussion, see Eskridge and Frickey, 45 Vand L Rev at 598-611 (cited in note 95). 
the rule of lenity." Indeed, when viewed in this sense, a clear statement rule that requires Congress to actually abrogate a treaty can be seen as nothing more than an effort to buttress and reinforce another statutory interpretation canon-the canon against implied repeals. ${ }^{12}$ In addition, this result also complies with standard treaty jurisprudence, which requires Congress to clearly indicate its intent to amend a treaty.

\section{Requiring Congress to bear the initial political costs.}

There are a number of normative justifications for applying a formalistic clear statement rule to buttress both the canon against implied repeals and the clear intent rule for treaties. Both of these judicially enforced guidelines for statutory construction are generally aimed at ensuring that Congress carefully considers the action it proposes to take. Such consideration is particularly important in the context of treaties because of their unique status as both domestic laws and international obligations. One major effect of requiring Congress to directly amend or abrogate the treaty is that it forces members of Congress to pay the political costs of such a change up front. The use of the "shall not construe" language in the Justice for POWs Act can be understood as an attempt by members of Congress to avoid the political costs on both the domestic and international fronts that would be associated with a congressional effort to actually amend or abrogate the treaty. ${ }^{114}$ Indeed, the legislation as drafted seems clearly aimed at allowing members of Congress to claim credit with the POW groups - who will understand that Congress created the conditions allowing them to recover - while at the same time being able to point to the federal courts as the guilty parties if they face criticism for abrogating the treaty.

111 See id at 599-601.

112 See, for example, Watt $v$ Alaska, 451 US 259, 266-67 (1981) ("[R]epeals by implication are not favored."); Morton v Mancari, 417 US 535, 549 (1974) (same); Posadas v National City Bank, 296 US 497, 503 (1936) (same). See also United States v Borden Co, 308 US 188, 198 (1939) ("The intention of the legislature to repeal must be clear and manifest.") (quotation marks omitted), quoting Red Rock v Henry, 106 US 596, 602 (1883).

113 See note 36.

114 As a matter of international law, the decision by a national legislature to abrogate a treaty, while perhaps politically controversial, is largely unremarkable. Nations abrogate and modify treaties with some regularity and the international system has developed a wide range of mechanisms to deal with such abrogation. See, for example, the Vienna Convention on the Law of Treaties, 8 ILM 679, Arts 54-64 (1969) (U.S. not a party) (discussing the termination and suspension of the operation of treaties).

115 See, for example, Statement of Congressman Dana Rohrabacher, Paying Homage to a Special Group of Veterans, Survivors of Bataan and Corregidor, 107th Cong, 1st Sess, in 147 Cong Rec H 3993-95 (July 12, 2001). 
It might be argued that given the sophisticated parties that are affected by this legislation - politically active citizens groups and foreign nations - such an attempt by Congress to shift the political costs to the courts is doomed from the start. While this is clearly correct in many respects, there are important limitations to this principle. First, it is important to note that the clear statement approach is not designed to account for long-term political costs; rather, it is designed to ensure that Congress accounts for the political costs immediately prior to and during debate over the resolution. Here, the notion of providing benefits to U.S. POWs who suffered deprivations at the hands of a wartime enemy is particularly politically appealing. Indeed, given our strong relationship with Japan in recent decades, it is reasonable to think that an individual member of Congress may discount the Japanese response to such legislation. As a result, a member of Congress may not accurately consider the international political costs of abrogation as weighed against the expected domestic political gain from supporting the politically influential POW groups. At the same time, the constructive abrogation approach is also attractive to members of Congress who are concerned about the potential international political costs but still support providing a remedy to American POWs. By using the courts as the mechanism for carrying out their preferred policy, members of Congress who are concerned about directly abrogating the treaty can justify a vote in favor of the U.S. POWs by arguing that while a direct abrogation may result in serious problems abroad, a more subtle and narrowly tailored change may be more acceptable at the margins. Indeed, this latter explanation provides a reasonable explanation for the actual wording of the Justice for POWs Act as a directive to the courts. This analysis suggests that in order to ensure that Congress properly accounts for the decision to constructively abrogate the treaty, it must be required to bear the political costs of abrogation up front-prior to and during the consideration of the Justice for POWs Act or similar legislation.

Requiring members of Congress to bear the political cost of abrogation up front would likely lead to a congressional debate over the costs and benefits of abrogation-a debate the Justice for POWs Act attempts to circumvent by using the courts to implement its legislative policy. It is important to note that the forcing effect of such a clear statement rule is crucial to the separation-of-powers values that the rule is attempting to protect. Even if one believes that Congress's intent to abrogate the treaty at issue in the Justice for POWs Act is clear, it still makes sense to select a rule that ensures proper consideration of consequences and protects the courts from political involvement. The underlying notion here is that Congress should not be able to use the federal courts as its tool to achieve politically 
controversial results, regardless of the circumstances. This approach parallels the typical application of the canon against implied repeals, which serves to ensure that Congress bears the political costs of repealing legislation and ensures that Congress, not the courts, is the prime mover in the legislative arena.

2. Leaving foreign affairs to the political branches.

Another important normative reason to apply a clear statement rule is that such an approach also comports with the Court's oftexpressed notion that foreign affairs issues are better left to the political branches. ${ }^{116}$ The clear intent requirement for amending a treaty reflects this concern with the institutional competence of the courts in foreign affairs. As such, the proposed clear statement rule can be seen as a strengthened and revitalized version of the clear intent requirement.

One of the key problems with the Justice for POWs Act is that it not only uses the courts as a tool to do what the Congress and the President are constitutionally charged to do-the enactment of a change in federal law-but that it does so with respect to a treaty. As a result, by attempting to constructively abrogate the Japan-U.S. Peace Treaty through the courts, Congress is forcing the judiciary to become directly involved in the very politically sensitive arena of foreign affairs.

Some may argue that this involvement is no different than in any judicial case in which foreign affairs are implicated. In addition, it may be pointed out that while courts may generally be reticent to become involved in foreign affairs disputes, by no means has the judiciary completely avoided such involvement. ${ }^{117}$ However, the unique form that the involvement engendered by the Justice for POWs Act takes renders the judiciary's involvement in this case somewhat more problematic. This is so because on its face the Justice for POWs Act does not actually amend the treaty and then require the courts to carry out the decision of the political branches. Rather, the POWs Act requires

116 See, for example, Oetjen $v$ Central Leather Co, 246 US 297, 302 (1918) (holding that "[t]he conduct of the foreign relations of our Government is committed by the Constitution to the Executive and Legislative - 'the political' - Departments of the Government" and that judicial inquiry into these areas is generally inappropriate); Whitney $v$ Robertson, 124 US 190, 195 (1888) (noting that the determination of foreign relations matters is not confided in the judiciary).

117 See Banco Nacional de Cuba v Sabbatino, 376 US 398, 423 (1964) (noting that "it cannot of course be thought that 'every case or controversy which touches foreign relations lies beyond judicial cognizance" "and holding that "[t]he text of the Constitution ... does not irrevocably remove from the judiciary the capacity to review the validity of foreign acts of state"), quoting Baker v Carr, 369 US 186, 211 (1962). 
the courts to be active participants in the actual abrogation of the treaty by having the courts ignore the treaty's plain language.

It may be argued that any opinion from a court that allows POWs to sue is likely to point to the Justice for POWs Act as the reason the suits are able to go forward; this would indicate that Congress, not the courts, is acting in the foreign affairs realm. The point this argument misses is the active role that the courts are forced to take in the political act of abrogation under this legislation. While the political branches have set the policy by enacting the statute, the courts are not only implementing congressional policy in particular cases (as is typical for any statute), but are required to read a treaty against its plain meaning to reach that result. That is, in this case, the courts not only enforce the policy of the political branches, but they become part of the process by which the policy is initially implemented, a role normally left to the executive branch. It is this unique problem that creates the threat to the proper separation of powers. Indeed, this problem of policy entanglement is only magnified when it takes place in the context of foreign affairs, where the political branches are intended to be the primary actors.

While this view of the Act is open to the criticism that it is overly formalistic, there are strong arguments for applying such a formal approach in the separation-of-powers context. Indeed, these arguments are especially applicable in the foreign affairs arena, where the courts have developed a wide range of doctrinal approaches to limit the very type of political entanglements that this legislation seems to create."

\section{B. Defending Formalism}

In applying the clear statement rule proposed above to the Justice for POWs Act, the Court would essentially be prohibiting Congress from employing its chosen method of achieving the result it seeks. Instead, the Court would require Congress to explicitly state its intention to abrogate the treaty. In a sense then, this formulation of a clear statement rule is somewhat more formalistic than other applications of clear statement rules. ${ }^{119}$ It requires Congress not only to care-

118 See, for example, Banco Nacional de Cuba, 376 US at 416 (discussing the act of state doctrine, which concerns the competency of dissimilar institutions to make and implement particular kinds of decisions in the area of international relations); Baker, 369 US at 211-13 (discussing the political question doctrine in the foreign relations context).

119 In other cases, the Court has applied a clear statement rule to situations in which Congress may properly override the constitutionally based value identified by the courts. In this way, the rules permit Congress to achieve its result through its chosen method, but only if Congress expresses its intent to do so using explicit and unambiguous language. For example, the Court has established super-strong clear statement rules to cabin congressional efforts to place federal conditions on state administration of federal programs, to waive states' Eleventh Amendment immunity, to regulate core state functions, to regulate intergovernmental taxation, and to apply 
fully consider the constitutional value at stake, but also to undertake its action in a manner that comports with the underlying constitutional value. ${ }^{120}$ That is, Congress may not engage in an attack on the separation of powers by using the courts to amend a treaty when it could actually amend the treaty itself.

It may be argued that such an approach simply serves to elevate form over substance. However, what is critically important is that this formal approach is aimed at achieving a very specific and substantive result-ensuring that the proper separation of powers is maintained between the judicial and legislative branches. It is important to remember that Congress could amend the treaty if it so desired. Thus, the only way in which the rule "elevates form over substance" is to prevent an attempt by Congress to use the federal judiciary as its legislative tool.

Judge Guido Calabresi has aggressively argued that formalism is particularly important in the separation-of-powers context. ${ }^{121}$ As Judge Calabresi points out, the separation-of-powers doctrine is "a structural safeguard" that establishes "high walls and clear distinctions." distinction is needed "because low walls and vague distinctions will not be judicially defensible in the heat of interbranch conflict." ${ }^{123}$ This argument essentially suggests that while flexibility may generally be useful in constitutional adjudication, interbranch conflicts raise the specter of one branch justifying its encroachment on the role properly

federal statutes to state and local political processes. See, for example, Gregory $v$ Ashcroft, 501 US 452, 460-62 (1991) (arguing that the federal courts must be certain of Congress's intent before finding that federal law overrides the constitutional balance of federal and state powers); Davis v Michigan Department of Treasury, 489 US 803, 813 (1989) ("When Congress codifies a judicially defined concept, it is presumed, absent an express statement to the contrary, that Congress intended to adopt the interpretation placed on that concept by the courts."); McNally $v$ United States, 483 US 350, 359-60 (1987) (holding that, given two readings of a criminal statute, one harsher than the other, a court will choose the harsher one only when "Congress has spoken in clear and definite language"); Atascadero State Hospital v Scanlon, 473 US 234, 242-43 (1985) (holding Congress must express its intention to abrogate the Eleventh Amendment in "unmistakable language"); Pennhurst State School and Hospital v Halderman, 451 US 1, 17 (1982) ("[I]f Congress intends to impose a condition on the grant of federal moneys, it must do so unambiguously."). In these cases, the Court held that where Congress explicitly overrides a constitutional value in the text of a statute, the judiciary will give effect to Congress's intent. Consider South Dakota v Dole, 483 US 203, 207 (1987) (upholding a condition on federal highway funds where Congress had clearly indicated its intent to place conditions on the funds).

120 This type of approach can be understood as adopting legal formalism as a pragmatic strategy. Because the desired end is to ensure that courts retain their interpretive role vis-à-vis treaties while preserving a role for Congress in amending or abrogating treaties on the domestic front, applying formalism to achieve this end is a wholly pragmatic approach. Consider Richard A. Posner, Law, Pragmatism and Democracy 49 (Harvard 2003) (discussing formalism as a pragmatic strategy).

121 See note 102.

122 Benjamin v Jacobson, 172 F3d 144, 180 (2d Cir 1999) (en banc) (Calabresi concurring).

123 Id, quoting Plaut, 514 US at 239. 
assigned to another under the cover of "flexibility." Therefore, where the branches come into conflict, it is important to have bright-line rules that delineate where the responsibilities of one branch end and those of another branch begin.

Indeed, as Martin Redish and Elizabeth Cisar point out, adopting a formalistic approach to the separation of powers is often the only way to ensure that the branches do not intrude upon one another's roles. ${ }^{124}$ In contrast, the "flexible" approach to the separation of powers, as adopted in Stockdale and Robertson, is really no approach at all-it does nothing to preserve the separation of powers between the judiciary and legislature and essentially allows the courts to be used as the legislative branch's tool in implementing politically controversial initiatives. In many ways, this is the very foundation of Klein: Congress cannot set out a rule of decision for the courts by intruding on their historic responsibilities. As a result, the formalistic approach makes sense not only in the context of treaty interpretation but can be understood as applying more broadly across the spectrum of separationof-powers conflicts. Indeed, one can already see the application of this formalistic approach in a variety of separation-of-powers cases outside the foreign affairs context."

Formalism, as applied to the Justice for POWs Act through a clear statement rule, requires Congress to be more politically accountable by forcing members of Congress to bear the political costs of treaty abrogation up front. In addition, formalism here ensures that the political branches grapple with important foreign affairs issues directly, rather than through the courts. This is particularly important in an area where the judiciary lacks institutional competence, at least relative to the political branches. In this sense, a bright-line rule in the foreign affairs arena is all the more important in preserving the separation-of-powers values discussed above.

\section{CONCLUSION}

The Justice for POWs Act forcefully raises the question of how far Congress may go in cabining the judiciary's historic role in interpreting treaties. As such, the Act is in tension with the structural constitutional values embodied in the separation-of-powers doctrine. In order to determine how best to preserve the values underlying this doctrine, it is helpful to recall James Madison's admonition in Federalist 51: "[T]he greatest security against a gradual concentration of the several powers in the same department, consists in giving to those who

124 See Martin H. Redish and Elizabeth J. Cisar, "If Angels Were to Govern": The Need for Pragmatic Formalism in Separation of Powers Theory, 41 Duke L J 449, 462-65 (1991).

125 See notes $100-02$ and accompanying text. 
administer each department, the necessary constitutional means, and personal motives, to resist encroachments of the others."

In the end, the duty to resist incursions by the legislative branch may fall to the "least dangerous branch." statement rule is one method that the judiciary can use to address legislative efforts to encroach upon the proper role of the courts in treaty and statutory interpretation.

126 Federalist 51 (Madison) at 349 (cited in note 21).

127 See Federalist 78 (Hamilton) at 522-23 (cited in note 27) (referring to the judiciary as the branch "least dangerous to the political rights of the constitution" because it "has no influence over either the sword or the purse"). See generally Alexander M. Bickel, The Least Dangerous Branch: The Supreme Court at the Bar of Politics (Yale 2d ed 1986). 


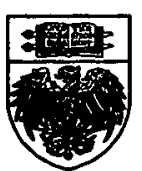

